\title{
Leaching requirements for salt-affected soils of West Nubian valley of Nile River (North Sudan)
}

\author{
Branislav Žeželj ${ }^{1}$, Predrag Dimovski ${ }^{2}$ \\ ${ }^{1}$ Branislav Žeželj, "Meling" Ltd. Comp., Marsala Tolbuhina no.13, 11080, Belgrade-Zemun, Serbia, \\ melingzezelj@gmail.com \\ ${ }^{2}$ Predrag Dimovski, Rudnist Engineering, Licka 20, 11000 Belgrade-Serbia \\ Corresponding author: Branislav Žeželj, melingzezelj@gmail.com
}

\section{ABSTRACT}

This paper is deducted to the theoretical studies and experimental determination of optimum leaching requirements for salt-affected lands of West Nubian Valley of Nile River, having different mechanical and chemical properties. Based on reviewing various references, summarizing the date obtained from the detailed field as well as from productive area experiments when reclaiming the first stage virgin land site West Nubian Experimental station to the objective, was to find the answer to the following important problems:

- What proper parameters of leaching checks, leaching borders and specific water discharge amount should be from the view point of a rational usage of a single cubic of water, labor power economy, expenditures, machinery and time?

- When leaching should be started and completed in order to perform all pre-sawing practices in time for succeeding in cultivating summer crops.

- What kinds of well-known theoretical relationships can be used to determine leaching requirement for salt-effected lands under the observed conditions.

- Find out the most appropriate equations which can be applied for predictive evaluation when designing optimum leaching requirements for the part of West Nubian Valley (North Sudan).

- Upon the study a different drain spacing calculation as well as adequate leaching infractures and land preparation took place, taking the proper soil management practice to be performed in time. 
- For predictive estimation of leaching requirement values the use of Volobuev's equation have been recommended, with " $\alpha$ " values: $1.27,1.03$, and 0.66 for heavy, medium and light soils respectively.

Keywords: reclamation production, ameliorative crop, initial salt leaching, crop rotation models.

\section{INTRODUCTION}

Salinity control is one of the principal problems of irrigated agriculture intensification and leaching practice is one of the basic soil management practices in the process of salt-affected lands reclamation.

Salinity of soils is caused by numerous climatic and water, main of which are:

- Poor natural drainage conditions resulting from extremely plain relief of lower West Nubian Valley, practically, has no run-off and with poor filtration properties of the Quaternary deposits.

- Fine-texture soils.

- Irrigation with artificial drainage practiced for centuries.

- Very often high water table, highly saline ground waters.

- Large irrigation network losses.

The soil contain a large variety of salts and salt combinations, but, practically, the combination formed from the salts of three acids (carbonic, sulphuric and hydrochloric) and three alkali (caustic calcium, magnesium, and sodium) predominant (Table 1).

Table 1 Main types of salts and their solubility

\begin{tabular}{llcc}
\hline \multicolumn{1}{c}{ Salts } & \multicolumn{1}{c}{ Formula } & \multicolumn{2}{c}{ Permissible soil salt content } \\
& & \% of soil weight & Solubility at $20^{\circ} \mathrm{Cg} / \mathrm{l}$ \\
\hline Potassium chloride & $\mathrm{KCl}$ & 0.60 & 340 \\
Calcium chloride & $\mathrm{CaCl}_{2}$ & 0.30 & 745 \\
Sodium chloride & $\mathrm{NaCl}$ & 0.20 & 360 \\
Magnesium chloride & $\mathrm{MgCl}_{2}$ & 0.40 & 545 \\
Sodium sulphate & $\mathrm{Na}_{2} \mathrm{SO}_{4}$ & 0.50 & 194 \\
Magnesium sulphate & $\mathrm{MgSO}_{4}$ & 0.50 & 445 \\
Sodium carbonate & $\mathrm{Na}_{2} \mathrm{CO}_{3}$ & 0.10 & 215 \\
Calcium nitrate & $\left.\mathrm{Ca}_{2} \mathrm{NO}_{3}\right)_{2}$ & 0.17 & 1293 \\
Sodium nitrate & $\mathrm{NaNO}_{3}$ & 0.25 & 845 \\
Potassium nitrate & $\mathrm{KNO}_{3}$ & 0.70 & 316 \\
\hline
\end{tabular}


It has been found that $\mathrm{pH}$ has a considerable influence in movement of nutrients and salts to the plant roots. Increase of soil alkalinity intensifies anion absorption by plant roots. In acid soils solubility of phosphates and adoption of them by plant roots becomes better. On the other hand, in the acidic media the solubility of aluminium increases abruptly, which has negative effect on plant development. While in alkali soils the various enzymes in plant roots decompose and nitrate and phosphate absorption of these plants decreases.

That is the reason why a neutral concentration of soil solutions has to be achieved i.e. $\mathrm{pH}$ should be equal to 7. In heavy solonetzic soils, $\mathrm{Na}$ cations dominate over $\mathrm{Ca}$ and $\mathrm{Mg}$ cations, while in non-solonetzic is vice-verse. The most soluble salts are harmful for normal plant development. Some of them, such as $\mathrm{Ca}\left(\mathrm{NO}_{3}\right)_{2}, \mathrm{KNO}_{3}, \mathrm{NaNO}_{3}$, and $\mathrm{KCL}$, exhibit their poisonous effect in soil, but if the soil-and-salt conditions are favourable they may appear to be good fertilizers stimulating progressive agriculture development (Hagen, 1967).

Usually mineral nutrition disturbance of most agriculture crops is caused by excess of $\mathrm{Cl}$ and $\mathrm{Na}$ ions in the soil. These ions limit the supply of other necessary nutritive elements to the plant. At $\mathrm{Cl}$ content 0.04 to $0.05 \%$ of soil weight, most of agriculture crops, are not only suppressed and produce no yield but even perish. At $\mathrm{SO}_{4}$ content more than $0.5 \%$ of soil weight (sulphate type salinity souls), most of crops starts to perish.

Table 2 Chemical composition of soil samples

\begin{tabular}{ccccccccccc}
\hline No. & Auger no. & $\mathrm{pH}$ & $\begin{array}{c}\mathrm{ECe} \\
\mathrm{mmhos} / \mathrm{cm}\end{array}$ & $\begin{array}{c}\mathrm{Ca} \\
\mathrm{me} / \mathrm{l}\end{array}$ & $\begin{array}{c}\mathrm{Mg} \\
\mathrm{me} / 1\end{array}$ & $\begin{array}{c}\mathrm{Na} \\
\mathrm{me} / 1\end{array}$ & $\begin{array}{c}\mathrm{P} \\
\mathrm{me} / \mathrm{l}\end{array}$ & $\begin{array}{c}\mathrm{Cl} \\
\mathrm{me} / 1\end{array}$ & $\begin{array}{c}\mathrm{SO}_{4} \\
\mathrm{me} / 1\end{array}$ & $\mathrm{Ca} \mathrm{HCO}_{3}$ \\
\hline 1 & No.1 & 7.6 & 34.3 & 113 & 133 & 113 & 0.88 & 308 & 55 & 2.21 \\
2 & No.2 & 7.9 & 10.9 & 28 & 53 & 89 & - & 93.2 & 88 & 1.10 \\
3 & No.3 & 7.8 & 20.5 & 71 & 85 & 98 & 0.73 & 214 & 26 & 1.60 \\
\hline
\end{tabular}

High concentration of salts in soil solution brings forward physiological dryness of plant roots and high osmotic pressure. It means that in order to increase soil fertility and achieve higher crop yields the root zone of soil must be relieved of toxic salts annually, prior to sowing.

\section{MATERIALS AND METHODS}

At present, there exist many effective methods of desalinization and salt neutralization of soil. Such are: leaching with non-mineralized water, supported by artificial, or natural drainage, electro reclamation (removal of salt by electrolysis), application of neutralizing chemical fertilizers with consideration of soil type, processing of seeds with saline ground 
water of corresponding area, prior to sowing, selection of salt-tolerant and salt-absorbed crops, application of gypsum, peat, sand, organic fertilizers and the like to get $3 /$ ha, with a complex of management practices.

However, till now, the most popular and economical method used in practice is desalinization of soils by means of leaching irrigation. Although this method has been used for centuries, it acquires a scientific basis during the 5-6 decades. A scientific basis means is that prior to leaching, a root zone of this soil layer is subjected to chemical and mechanical analysis and according to hydro geological conditions, type and degree of soil salinity, a certain leaching amount is applied respectively for each location, region or small field area, encircled in a contour (Aidarov, 1971).

In reclamation practice many semi-empirical theoretical and practical methods of leaching requirement calculations are known.

To determine leaching requirements six chemical elements should be obtained from a soil extract: $\mathrm{Cl}, \mathrm{SO}_{4}, \mathrm{HCO}_{3}, \mathrm{Ca}, \mathrm{Mg}, \mathrm{Na}$ and $\mathrm{K}$. Than these elements are compounded into salts available in the given soil and calculation of leaching requirements follows. The soil samples have been taken up to $1 \mathrm{~m}$ depth and mixed to achieve an average representative sample. The following salts and their percentage are obtained: $\mathrm{Ca}\left(\mathrm{HCO}_{3}\right)_{2}=0.00336, \mathrm{CaSO}_{4}$ $=0.16, \mathrm{MgSO}_{4}=0.0618, \mathrm{NaSO}_{4}=0.1357, \mathrm{NaCl}=0.0064$.

All the chemical and physical analysis of soil and ground water were performed in College of Agriculture laboratory, Sudan University for Science and Technology (Table 2.)

When anions and cations have been expressed by salt formulae, the following data are obtained (Table 3).

Table 3 Salt composition of soil samples

\begin{tabular}{lllllllll}
\hline SL No & Sampling & Salt, $\%$ & \multicolumn{5}{c}{ Including meg/per 100 g soil } \\
& plot & & $\mathrm{Cl}$ & $\mathrm{SO}_{4}$ & $\mathrm{HCO}_{3}$ & $\mathrm{Ca}$ & $\mathrm{Mg}$ & $\mathrm{Na}+\mathrm{K}$ \\
\hline 1. & W.N.V1 & 1.05 & 8.85 & 7.3 & 0.14 & 1.6 & 4.3 & 108 \\
2. & W.N.V2 & 2.40 & 30.8 & 5.5 & 0.22 & 11.3 & 13.3 & 11.3 \\
3 & W.N.V3 & 1.33 & 15.37 & 4.84 & 0.045 & 2.22 & 5.67 & 11.17 \\
\hline
\end{tabular}

The possibility of soil salinization has been checked by the formula suggested by Vilensky, Mozheiko and Vorotnik:

$$
\mathrm{Na}^{++} / \mathrm{Ca}^{++}+\mathrm{Mg}^{++}=>2-4
$$

In our case the soils are not subjected to salinization since cation parts (relationship), ratio ranges between $0.46-1.8$. 
To obtain a leaching requirement value, using Cherkasov formula the following factors should be determined:

- Total amount of toxic salts in soil,

- Moisture holding capacity of soil.

- Soil porosity and

- Specific gravity of soil Skeleton (Bulk Density).

Thus the equation will be:

$$
\mathrm{S} \times \mathrm{W}^{\mathrm{n}} /(\mathrm{w}+\mathrm{a})^{\mathrm{n}}=\mathrm{S}_{1} \times \mathrm{N}_{\text {net }}=\mathrm{w}+\mathrm{a} \times \mathrm{n} \quad \mathrm{M}^{3} / \mathrm{ha}
$$

Where, $\mathrm{n}$ - number of leaching, $\mathrm{w}$ - moisture holding capacity $\mathrm{M}^{3} / \mathrm{ha}$, s - initial salt content, ton/ha, $\mathrm{s}_{1}$ - maximum permissible salt content, ton/ha, a - water below desalinized layer, more than moisture holding capacity, $\mathrm{M}^{3} / \mathrm{ha}$.

$$
\mathrm{n}=\lg \times \mathrm{S}_{1}-\lg \mathrm{S} / \lg \mathrm{W}-\lg (\mathrm{W}+\mathrm{a})
$$

Using the chemical analysis data of salts solid residue in a meter layer, leaching requirement can be obtained by Volobuev's formula (Volobuev, 1975).

$$
\mathrm{N}_{\text {net }}=10.000, \mathrm{~h} \times \lg \left(\mathrm{S} / \mathrm{S}^{1}\right) \mathrm{x} \propto
$$

Where, $\mathrm{h}$ - thickness of soil layer after leaching, $\alpha$ - factor raring between 0.62 and 3.3.

So the net leaching requirement will correspond to: $6.63,7.87$ and 8.83 thousand $\mathrm{M}^{3} / \mathrm{ha}$, respectively.

Having in mind all the above mentioned, Table 4, represents the data bases on practical and scientific-research experience in leaching of salinized lands, the data obtained under different hydro-geological and reclamation conditions.

\begin{tabular}{|c|c|c|c|c|c|c|c|}
\hline \multirow{4}{*}{ No } & \multirow{4}{*}{$\begin{array}{c}\text { Dry or solid } \\
\text { residue of salts \% }\end{array}$} & \multicolumn{6}{|c|}{ No drainage and insufficient drainage } \\
\hline & & \multicolumn{4}{|c|}{ Loamy sand, light and moderate loam } & \multicolumn{2}{|c|}{ Heavy loam clay soils } \\
\hline & & \multicolumn{2}{|c|}{ Water table } & \multirow{2}{*}{$\begin{array}{l}\mathrm{N} \\
3.5\end{array}$} & \multicolumn{2}{|c|}{ Water table } & \multirow[b]{2}{*}{35} \\
\hline & & 1.5 & 2.5 & & 1.5 & 2.5 & \\
\hline 1 & 0.3 & 0.96 & 0.60 & 0.60 & 0.96 & 0.96 & 0.60 \\
\hline 2 & 0.5 & 2.47 & 1.66 & 1.16 & 3.02 & 2.33 & 1.34 \\
\hline 3 & 0.7 & 3.98 & 2.72 & 0.72 & 5.08 & 3.70 & 2.10 \\
\hline 4 & 1.0 & 6.24 & 4.32 & 2.56 & 8.16 & 5.76 & 3.20 \\
\hline 5 & 1.3 & 7.31 & 5.18 & 3.47 & 9.53 & 6.90 & 4.17 \\
\hline
\end{tabular}

Table 4 Leaching requirements in accordance with drainage conditions, solid residue of salt (ECe), ground water table and soil texture 


\section{RESULTS AND DISCUSSIONS}

The complex of investigations of salt-affected land reclamation includes also experiments aiming at discovery the correlative relationship between leaching, irrigation regimes and cultivated crops on the one hand and physical, chemical and diffusive salt movement on the other.

This experiment should be conducted both without drainage conditions and supported by drainage of various types and design. The above mentioned allows obtaining optimum leaching requirements and vegetative-irrigation requirements promoting progressive salt removal and soil fertility increase.

In addition, the results obtained will help in a proper water usage planning for agriculture farms and in managing more effectively water resources of the country.

Drain spacing and diameters of pipes of uniform design i.e. $75 \mathrm{~m}$. Each plot is supplied with 5 subsurface drains. Two of them, extreme, perform as buffer drains, and 3 other drains, in between, serve as test ones. Design and materials of the drain pipes and filters of the test drains were of different types.

The length of the subsurface drains is uniform for all types of drains and is $200 \mathrm{~m}$. Each plot had a dense network having filters at 3, 5, 9, and $25 \mathrm{~m}$ depth. All types of irrigation and drainage canals were supplied with the hydrometric installation required (Kostjakov, 1960).

The overall leaching requirement values varied from 2 to $18.5 \mathrm{~m}^{3} / \mathrm{ha}$.

The objective of the leaching trials was to find out the answer to the following problems:

1. What proper dimensions of a leaching check should be?

2. What soil management practices assisting reduction of a leaching period will be?

3. What are the actual leaching requirements values capable to desalinize $1 \mathrm{~m}$ soil?

4. Could any theoretical or semi-empirical formula Volobuer's equation in particular, be applied, to estimate leaching requirement? If so, what is " $\propto$ "value for conditions of North Sudan?

After leaching the test area was cultivated with various agriculture crops such as: cotton, green gram, sorghum, alfalfa, maize and sunflower, with an average harvest were: Maize - $3.130 \mathrm{t} / \mathrm{ha}$ (cultivated area $0.7 \mathrm{ha})$, sunflower - $1.275 \mathrm{t} / \mathrm{ha}(0.35$ ha cultivated area), green gram - $0.52 \mathrm{t} / \mathrm{ha}$ (3.6 ha total cultivated area). 
Prior to leaching, the ground water table of the plot fluctuated from $1.9-2.5 \mathrm{~m}$ depth and its salinity content $\left(\mathrm{ECe} \times 10^{3}\right.$ at $25^{\circ} \mathrm{C}$ ) ranged between 35 and 50 .

Before leaching, the detailed survey on all test plots was performed. This survey indicated very high salinity of the area, especially in its upper soil layer. Deeper survey revealed that the upper horizons of the earth's crust to $25.5 \mathrm{~m}$ depth were highly salinized. Chemical and mechanical soil analyses to 25.5 depths are given in Table 5.

The best results, from the point of view of even water distribution were achieved on $35 \mathrm{~m}$ wide by $50 \mathrm{~m}$ long leaching check (Eremenko et al., 1968). The leaching borders should be elevated $40 \mathrm{~cm}$ above the check surface, and the stream size should be $25 \mathrm{~L} / \mathrm{sec}$.

The total amount of water applied to the test plots in the process of leaching is shown in Table 6.

Table 5 Chemical and mechanical soil parameters obtained from Piezometers

\begin{tabular}{|c|c|c|c|c|c|}
\hline \multirow{2}{*}{$\begin{array}{l}\text { Samples depth } \\
\text { (m) }\end{array}$} & \multirow{2}{*}{$\begin{array}{c}\text { Sat.ext. ECe } \\
\text { mmhos/cm }\end{array}$} & \multicolumn{4}{|c|}{ Mechanical analysis \% } \\
\hline & & Sand & Silt & Clay & Tex. Lab. \\
\hline $0-5$ & 11.82 & 2.8 & 50.5 & 46.8 & $\mathrm{Si} \mathrm{C}$ \\
\hline $5-10$ & 15.73 & 7.9 & 54.0 & 42.4 & $\mathrm{SiCL}$ \\
\hline $10-15$ & 15.17 & 20.3 & 41.0 & 40.0 & $\mathrm{SiCl}, \mathrm{Cl}$ \\
\hline $15-20$ & 17.00 & 72.6 & 50.6 & 110 & SCL \\
\hline $20-25$ & 15.40 & 85.3 & 15.2 & $12, .0$ & LS \\
\hline
\end{tabular}

Table 6 Total water amount applied to test plot no.1 during leaching period

\begin{tabular}{|c|c|c|c|c|c|c|c|c|}
\hline \multirow[b]{2}{*}{ Plot no } & \multirow[b]{2}{*}{$\begin{array}{c}\text { Block } \\
\text { No. }\end{array}$} & \multirow[b]{2}{*}{$\begin{array}{c}\text { Area, } \\
\text { ha }\end{array}$} & \multicolumn{3}{|c|}{ Over all, $\mathrm{M}^{3} / \mathrm{ha}$} & \multicolumn{3}{|c|}{ Net $M^{3 \text { ha }}$} \\
\hline & & & $1^{\text {st }}$ leaching & $2^{\text {nd }}$ leaching & Total & $1^{\text {st }}$ leaching & $2^{\text {nd }}$ leaching & Total \\
\hline \multirow{5}{*}{1} & 1 & 14 & 3194 & 2996 & 6190 & 2877 & 1929 & 4806 \\
\hline & 2 & 1.4 & 3422 & 3396 & 6818 & 3117 & 2578 & 5695 \\
\hline & 3 & 1.4 & 3468 & 2944 & 6412 & 3296 & 2481 & 5777 \\
\hline & 4 & 1.4 & 3427 & 2939 & 6366 & 3307 & 2303 & 5610 \\
\hline & 5 & 2.85 & 3111 & 3407 & 6518 & 2787 & 2405 & 5192 \\
\hline
\end{tabular}

The leaching practices have been performed in three stages (Dieleman, 1973):

1. A field was ploughed up to $15 \mathrm{~cm}$ deep. Leaching water then was continuously applied with leaching requirement net about $5.5-6.0 \mathrm{~m}^{3} / \mathrm{ha}$.

2. After complete infiltration, soil and water samples for chemical analysis were taken and leaching requirement net of $202.8 \mathrm{~m}^{3} /$ ha was applied again. 
3. When this water amount also infiltrated the soil survey was done, the field was ploughed $10-15 \mathrm{~cm}$ deep and the portion of water about $4.2-4.3$ thousand $\mathrm{m}^{3} /$ ha net was applied to continue leaching practices.

4. Net total leaching requirements was between $12,45-12,84$ thousand $\mathrm{m}^{3 /} /$ ha and the total leaching time amounted to 178 days.

After complete infiltration the salt survey was done and the checks were flooded with water again, with about 3.5 thousand $\mathrm{M}^{3}$ leaching requirement net. The end of the leaching practice was considered the day when the block was completely dry and could plough it with tractors.

Analyzing the above results it should be noted that practically, to leach the soil area it is needed 72 days by applying a total leaching requirement net of 7.05 thousand $\mathrm{M}^{3} / \mathrm{ha}$. However, the average actual infiltration rate was $16 \mathrm{~mm} /$ day since the open water surface over leaching checks was recorded to be only 44 days.

Summarizing all data obtained from the field detailed trials and from the productive experiments it is well suggested to apply while developing salt effected lands, the following leaching requirement net values (Table 7).

Table 7 Leaching requirement values for a meter soil depth for salt-affected lends, having drainage conditions

\begin{tabular}{llll}
\hline \multirow{2}{*}{$\begin{array}{l}\text { Salinity } \\
\text { mmhos/cm }\end{array}$} & \multicolumn{3}{c}{ Leaching requirement, net, thousand $\mathrm{m}^{3} / \mathrm{ha}$} \\
\cline { 2 - 4 } & Heavy soils & Medium soils & Light soils \\
\hline $4-8$ & $1.5-5.4$ & $1.3-4.4$ & $0.8-2.8$ \\
$16-32$ & $5.4-7.65$ & $4.4-6.2$ & $2.8-4.0$ \\
$32-64$ & $7.65-11.5$ & $6.2-9.3$ & $4.0-6.0$ \\
\hline
\end{tabular}

\section{CONCLUSIONS}

Considering the results of theoretical, experimental and productive leaching investigation of the soils with different salinity degree and mechanical composition, the following main conclusions can be made:

1. For field with $75 \mathrm{~m}$ spaced field drainage, the most effective and economical proved to be leaching checks with a length of $50 \mathrm{~m}$ and width of $35 \mathrm{~m}$.

2. The height of checks should be $40 \mathrm{~cm}$; stream size should be about $25 \mathrm{~L} / \mathrm{check}$.

3. Shortening of leaching period is one of the most important factors when developing new lands. This especially concerns soil management practices timely performed. 
4. When practising leaching on heavy, strongly and moderately salinized soils, the following sequences should be observed:

- On ploughed, divided into leaching checks field, water amount of about $1.2-2.0$ thousand m'/ha, should be applied.

- 6-10 days later water amount of 1-1.5 thousand $\mathrm{m}^{3} /$ ha is added.

- It is advisable, when constructing new check borders to displace them from their original positions.

- On heavy salinized and on heavy soils (having soil drainage system), permits to complete leaching practices applying up to 12 thousand $\mathrm{m}^{3} /$ ha leaching requirement net.

- On light soils, after deep ploughing and check arrangement, leaching should be practised continuously upon the design.

- Leaching of heavy textured soils requires special care when beginning irrigation of all agriculture crops despite the methods of sowing: by furrows, strips or by checks.

Such experiments, both leaching practices and different irrigation regime investigations should be performed in some presentative projects in order to work out reclamation criteria required for all salt-affected lands in arid and semi-arid region of the same or similar conditions of a multi layer anisotropic soil. These experimental data will help to carry out rational water management planning for agriculture farms and to use water resources of the country more effectively.

\section{REFERENCES}

Averianov SF. 1971: Salinity control of irrigated lands, theory and practice, Moscow, Kolos Allison LE, Brown JW, Hayward HE. 1969: Diagnosis and Improvement of saline and alkali soils, USA Salinity Lab. Staff. Agriculture handbook no 60, August

Aidarov IP. 1971: Measures aimed at salinity control of irrigated lands. Moscow, Kolos publisher

Dieleman PJ. 1973: Reclamation of salt-affected soils in Iraq. ILRI, Publication 11, Wageningen.

Eremenko GV, Usmanov A, Heints RA. 1968: Quantitative analysis of irrigation waters. Hydro Engineering and Reclamation, Journal, no 7.

Hagen RM. 1967: Irrigation of Agricultural lands. Agronomy monographs no 11, ASA. 
Israelson OW. 1962: Irrigation principles and practices, Third edition, New York, London. Kostjakov AN. 1960: Foundation of reclamation, Moscow, Kolos.

Volobuev VP. 1975: Estimation of leaching requirements of salt-affected soils. Moscow, Kolos Publisher

Volobuev V. 1965: Salt removal investigations applying monolith leaching technique. Sci. Acad. report. Vol XXI no 5. 


\title{
NORME I ZAHTEVI ZA ISPIRANJE SOLI SLANIH ZEMLJIŠTA ZAPADNE NUBIAN DOLINE REKE NIL (SEVERNI SUDAN)
}

\author{
Branislav Žeželj ${ }^{1 *}$, Predrag Dimovski ${ }^{2}$ \\ ${ }^{1}$ Branislav Žeželj, "Meling” Ltd. Comp., Marsala Tolbuhina no.13, 11080, Belgrade-Zemun, Serbia \\ ${ }^{2}$ Predrag Dimovski, Rudnist Engineering, Licka 20, 11000 Belgrade-Serbia \\ *Corresponding author: Branislav Žeželj, melingzezelj@gmail.com
}

\section{IZVOD}

Studija je izvedena iz teorijskih analiza, kao i eksperimentalnih ispitivanja optimalnih zahteva za ispiranje soli iz zasoljenih zapadne Nubian Doline uz reku Nil, različitih fizičkomehaničkih i hemijskih osobina.

$\mathrm{Na}$ osnovu pregleda i analize različitih referensi, sumirajući dobijene podatke detaljnih poljskih i proizvodnih eksperimntalnih istraživanja reklamacije zemljišta, prva faza ispitivanja u okviru stanice West Nubian Valley, imala je za cilj odgovore na sledeca bitna pitanja:

- Koji su to parametri ispiranja soli iz basena i leja, sa aspekta potrebnih količina vode, te racionalnog korišćenja reklamativnih inputa, potrebne radne snage, ekonomskih pokazatelja, odnosno troškova mehanizacije za unapred definisano vreme-trajanje inicijalnog ispiranja soli?

- Kada process ispiranja soli iz zemljišta dinamički započinje i završava, sa ciljem izvođenja svih neophodnih pred setvenih priprema u cilju pravovremene i uspešne poljoprivredne proizvodnje u letnjem periodu?

- Koje se sve vrste dobro poznatih teoretskih međuzavisnosti mogu koristiti u cilju determinacije zahteva za ispiranjem soli ispitivanih zemljišta?

- Ispitati i potvrditi najpogodnije jednačine i postojeće teoretske formule u cilju projekcije i dizajniranja optimalnih ispirnih zahteva i evoluacije dibijenih rezultata za područje West Nubian Valley-Severni Sudan. 
- U okviru studije, analizirane su različite metode proračuna drenažnih rastojanja, ispirne infrastructure, te pripreme zemljišta, sve u cilju definisanja i praktične primene optimalnog modela reklamativnog menadžmenta.

- U cilju prediktivnog proračuna potrebe i dinamike ispiranja soli iz zemljišta, predlaže se korišćenje Volubijeve jednačine sa vredostima: 1 1.27, 1.03 I 0.66., za zemljista teskog, srednjeg I lakog mehanickog sastava.

Ključne reči: reklamativna proizvodnja, meliorativna kultura, inicijalno ispiranje soli, model rotacije useva. 